University of Wollongong

Research Online

Faculty of Law, Humanities and the Arts Papers (Archive)

Faculty of Arts, Social Sciences \& Humanities

$1-1-2015$

The rise of the global south, the IMF and the future of law and development

Gabriel Garcia

University of Wollongong,ggarcia@uow.edu.au

Follow this and additional works at: https://ro.uow.edu.au/lhapapers

Part of the Arts and Humanities Commons, and the Law Commons

Research Online is the open access institutional repository for the University of Wollongong. For further information contact the UOW Library: research-pubs@uow.edu.au 


\title{
The rise of the global south, the IMF and the future of law and development
}

\begin{abstract}
Following the onset of the Asian Financial Crisis the world has witnessed a re-accommodation of the global financial system. In the particular case of middle-income countries they have disentangled themselves from the conditionality of the IMF and grown into more assertive actors in international forums, proposing new alternative mechanisms to become more financially independent and for the provision of development assistance. This article critically reviews the new reality by assessing the strategies deployed by developing countries to reduce the IMF's influence, and explores the potential consequences of the rise of middle-income nations for Law and Development.
\end{abstract}

\section{Keywords}

south, global, development, rise, law, future, imf

Disciplines

Arts and Humanities | Law

\section{Publication Details}

Garcia, G. (2016). The rise of the global south, the IMF and the future of law and development. Third World Quarterly, 37 (2), 191-208 


\title{
The rise of the global south, the IMF and the future of Law and Development
}

\begin{abstract}
After the onset of the Asian Financial Crisis, the world has witnessed a reaccommodation of the global financial system. In the particular case of middleincome countries, they have disentangled themselves from the conditionality of the International Monetary Fund (IMF) and grown into more assertive actors in international forums, proposing new alternative mechanisms to become more financially independent and for the provision of development assistance. The article critically reviews the new reality by assessing the strategies deployed by developing countries to reduce the IMF's influence and explores the potential consequences of the rise of middle-income nations for Law and Development.
\end{abstract}

Keywords: Law and Development; IMF; Global South; BRICS; Banco del Sur, cooperation South-South, Chiang Mai Initiative Multilateralisation

This is an Accepted Manuscript of an article published by Taylor \& Francis Group in Third World Quarterly on 16 December 2015, available online: http://dx.doi.org/10.1080/01436597.2015.1108826

\section{Introduction}

The first two decades of the twenty-first century have witnessed the flourishing of economies in the Global South. After the stormy 1990s when economies in Asia and Latin America were struck by financial crises, countries in both regions have steadily grown, demonstrating strong resilience during the Global Financial Crisis (GFC). Emerging economies are no longer the needy clients of the International Monetary Fund (IMF) that now looks for new 'clients' elsewhere.

In contrast to the 'one-model-fits-all' approach of IMF programs in the 1990s, the transition from a state in crisis to a flourishing state has been achieved through different paths where each country adopted its own tailored model. In their relations with the IMF, the situation of these countries has changed since the Asian Financial 
Crisis of 1997-98 (AFC). Developing countries have implemented diverse strategies to reduce their dependency on IMF financial assistance. Simultaneously, and with a sound financial position at home, emerging economies now seek greater influence in the global financial order, not only claiming a more influential voice in traditional forums but also proposing new initiatives.

Due to the new reality, questions arise as to the consequences of this reaccommodation for the IMF and whether the rising contribution of developing countries to the global economy will be accompanied by a concomitant increase in their influence on the global order that will, in turn, be reflected in the practice of Law and Development. Whereas this is a field that has been highly influenced by the debate on the meaning of 'development' and the provision of development assistance, this article limits its scope to critically reviews the strategies implemented by developing countries to reduce their dependence on IMF financial assistance as well as to build a more inclusive and pluralistic global financial order.

The article observes that the strong resurgence of emerging economies has not been accompanied by an equivalent rebalance in the influence of these economies in international forums, including the IMF whose governance reform package has not yet entered into force due to the lack of support from the United States. In spite of the long way ahead, developing countries have become more assertive on the international stage and have launched new alternatives. This new reality should contribute with the definition of a more pluralistic agenda for Law and Development. 


\section{Law and Development prior to the Global Financial Crisis (GFC)}

For decades, academics have studied the interaction between legal institutions and development, leading to the creation of a body of knowledge that has been known as 'Law and Development'. Trubek and Santos, and Ohnesorge define it as a field that focuses on the socio-economic role of law in supporting development. ${ }^{1}$ It is influenced by disciplines such as economic theory, development theory, and politics as well as the policies and practices of development organisations and international financial institutions (IFIs). Since its inception, Law and Development has been tied to the financial and development assistance provided by national development agencies and IFIs and it has been influenced by the debate on what 'development' means. Trubek and Santos divide the history of Law and Development into three phases. ${ }^{2}$ The following paragraphs briefly review these three 'moments'.

The seminal work of Max Weber and the theory of modernisation contributed to the genesis of the first Law and Development movement. For Weber, a modern economy required a predictable legal system, 'the functioning of which is calculable in accordance with rational rules. ${ }^{3}$ Only the West, Weber argued, experienced a complete development of its legal system that was systematically elaborated and separated from other non-legal norms. The development and maintenance of this 'rational order,' Weber argues, has been managed by people who have received legal training. Furthermore, the process used (and continues to use) deductive and rational methods very different from customary-normative systems. Weber concludes that it is thanks to this progress of law that capitalist economies involved gained the stability they needed to flourish. For this author, only countries with 'legal rationality' were capable of achieving full industrialisation. ${ }^{4}$ 
The initial Law and Development movement was primarily conceived in the Unites States, and was closely related to the American government's foreign aid policy provided during the 1960s to assist developing countries in Latin America and Africa. This school of thought proposed the use of 'modern law' as an instrument to achieve social change. For the proponents of Law and Development, modern law was uniform, transactional, purposive, universal, hierarchical, rational and professional. ${ }^{5}$ During this first 'moment', Law and Development proponents suggested developing countries should undertake legal reforms to adopt modern law. This law was the opposite of the 'customary law' and 'traditional' institutions that were, it was argued, unsuitable to the achievement of progress. ${ }^{6}$ Based on these principles, the efforts of the Law and Development movement were oriented towards modernising traditional societies by transplanting legal models from developed nations. The state, assisted by foreign donors, would have a predominant role at this stage in the management of the modernisation process.

In a 1972 article, Trubek criticised what he called the 'core conception of modern law. ${ }^{7}$ He argued that it was erroneously assumed that Western law was essential for development. Trubek claimed that the core conception devoted too much effort to the implementation of Western law in developing countries, instead of understanding the legal systems of those nations. Two years later, Trubek and Galanter's article, 'Scholars in Self-Estrangement', ${ }^{8}$ declared a crisis in Law and Development studies. Both authors criticised the 'liberal legalism' paradigm that was the basis of the initial Law and Development movement.

The Law and Development debate was revived during the 1980s, aided by the theory of institutional changes and the work of Douglass North. This author affirms that institutions matter and are an important determinant of the long-term performance of 
economies because they have an effect on the cost of exchange and production. ${ }^{9}$ For this author, '[t]he inability of societies to develop effective, low-cost enforcement of contracts is the most important source of both historical stagnation and contemporary underdevelopment in the Third World' ${ }^{10}$ IFIs started to design a new strategy on the grounds of his work, emphasising the importance of the rule of law to a market economy and for achieving development. ${ }^{11}$ The IMF followed this path and became involved with the ex-Soviet republics, assisting them in building a legal and institutional framework for a market economy. ${ }^{12}$ A similar strategy of strengthening legal institutions to open closed economies was also promoted by the IMF in Latin American, Asia and Africa. ${ }^{13}$

The second 'moment' in Law and Development was inspired by neo-liberal economic theories and was primarily focused on strengthening legislation and institutions associated with business, foreign investment and the private sector. ${ }^{14}$ It was believed that economic reforms and the improvement of economic growth would automatically spread to other aspects of development. As a consequence, developing countries were convinced by IFIs (including the IMF) to implement standardised legal and economic reforms as a condition for receiving financial aid that would help to address financial crises. Changes were inspired by 'best practices' as had been applied in developed nations. ${ }^{15}$ Typical IFI programs focused on areas such as legislation required to support trade and foreign investment, banks, liberalisation of financial markets, protection of intellectual property, improvement of courts, and creation of alternative dispute resolution schemes. The main criticism of the neo-liberal rule of law was its excessive market fundamentalism and the importance placed on the transplantation into developing countries of legislation inspired by norms enforced in developed nations without considering the economic, cultural and social context of the recipient country. 
In this second wave, some efforts were directed to discuss the relevance of the rule of law not only to achieving economic development but also to promoting democracy and human rights; however, the debate was dominated by the former and, for example, greater emphasis was given to the protection of economic rights. Similarly to the first wave of Law and Development, the neo-liberal rule of law relied heavily on models designed in forums controlled by major industrialised countries with little or no consideration of the domestic context of the developing countries into which the models were to be transplanted. In this moment, the focus of Law and Development changed from formal law to a thin notion of rule of law that was used to convince the South of the importance of adopting market legal institutions to achieve development. ${ }^{16}$

During this second moment, research by a group of scholars who had been working on East Asia became more visible. Their research revealed that various countries demonstrated a successful economic development record that was not being supported by a formal rule of law context. This line of research — referred to by Scott Newton as the 'Second Commonwealth School' — aims to understand the role played by law in the successful development of East Asia. It assumes a more holistic approach and studies law in the social and cultural context of each country. ${ }^{17}$

In the beginning of the twenty-first century, the rule of law maintained a crucial role in IFI development strategies; however, international institutions tried to reduce the influence of neo-liberalism in favour of other elements embraced in the concept of development. In this third stage, which coincided with the launch of the Comprehensive Development Framework by the World Bank, the rule of law seemed to be a mechanism through which to guarantee the openness of markets, the protection of human rights and the promotion of democracy. In other words, while the doctrinal position of the third moment still supported neo-liberalism and the strengthening of private law, it also 
recognised the need for the construction of a more comprehensive legal framework which would encompass not only the protection of rights associated with the economy, but also other 'universal principles'. Using this approach, IFIs started to promote reforms oriented towards strengthening a notion of rule of law that would serve as a pillar for the promotion of human rights and democracy as well as of the market.

The World Bank and the IMF subscribed to the new approach, calling for the promotion of the comprehensive model of development that addressed not only economic development but also the social, political, human and legal perspectives of the process. ${ }^{18}$ Within this broader concept of development, the IMF created the Poverty Reduction and Growth Facility (PRGF) in 1999 (replacing the Enhanced Structural Adjustment Facility) in order to connect its financial objectives with the goal of reducing poverty. For this reason, the IMF's lending operations accommodated higher public expenditure directed at tackling poverty. ${ }^{19}$

The adoption of a broader notion of the rule of law in the third moment and the acceptance of a more comprehensive understanding of the concept of development have contributed to expanding the field of Law and Development. The main features of the third moment are the inclusion of the human rights debate in the context of Law and Development at a similar level to the economic factor. Rather than waiting for economic reforms to permeate other spheres, the third moment tries to address the rule of law from different perspectives (e.g. economic, human rights, etc.). This reality has increased the number of new actors that have joined the conversation, reducing the influence of traditional IFIs that dominated the debate during the two initial moments. ${ }^{20}$ 


\section{Rebalancing the global financial order}

As was briefly explained in the previous part, the IMF and other IFIs were key players in the promotion of the agenda of Law and Development between the 1980s and the beginning of the 2000s. From 2005, they have had a more modest influence whilst middle-income countries have strengthened their financial position and steadily increased development cooperation assistance to other less developed countries. This South-South cooperation has been promoted without a clear agenda for Law and Development, just as it had been in the case with IFIs in previous past decades. Thus, it is open to discussion whether a fourth moment of Law and Development has emerged. The novel switch in power relations was a response to various factors; however, an element common to many developing countries was the discontent produced by the IMF programs in the 1990s. Resentment towards IMF programs encouraged these nations to explore means to reduce IMF interference in domestic affairs.

When developing countries started implementing various mechanisms to diminish IMF influence, the approach negatively affected the institution. Few people remember the critical situation in which the IMF was immersed prior to the onset of the GFC. It was facing its own crisis, trying to survive financially and rebuild a reputation that had been damaged by its management of financial crises in Latin America and Asia where IMF-sponsored reforms inflamed residents of cities from Ciudad de Mexico to Buenos Aires and from Seoul to Bangkok. It was common to see widely-broadcast events where a humiliated president or prime minister — who had been basically rushed to agree on the implementation of an IMF-sponsored program — was shown with a smiling IMF Managing Director, signing a Stand-By Arrangement (SBA), accepting the adoption of the IMF 'recipe' in exchange for financial assistance. ${ }^{21}$ 
Under these SBAs (which the IMF Guidelines on Conditionality stated were not legal agreements), ${ }^{22}$ countries had to adopt a neo-liberal program that embraced the set of prescriptions included in the so-called Washington Consensus. Measures to be adopted included fiscal discipline, re-ordering public expenditure priorities (away from subsidies), tax reform, financial liberalisation, unified exchange rates, trade liberalisation, liberalisation of foreign direct investment, privatisation of state enterprises, deregulation, and protection of property rights. ${ }^{23}$ The key strategy of the neoliberal recipe was 'less government intervention, more freedom in the market'. ${ }^{24}$ The formula would, it was widely believed by post-Keynesian economists and advisers, bring prosperity and development to poorer countries. Despite such ostensibly good intentions, the implementation of IMF programs in many cases exacerbated the consequences of crises and increased social and economic instability as well as inequality. $^{25}$

Due to the negative social, political and economic impact of IMF programs, discontent with the IMF grew, prompting developing nations to think of ways to reduce IMF ascendancy in their regions. It would be beyond the bounds of the present article to explain in detail each of the mechanisms deployed by developing countries to regain control of their domestic financial affairs; however, the author will review four of the mechanisms supported by the Global South (below).

\section{International reserves}

One of the first measures put in place by developing countries to reduce IMF influence was the accumulation of international reserves. Should financial crises arise, these resources would serve as the first line of defence and provide the necessary liquidity for nations affected instead of those nations applying for IMF financial assistance. Most 
countries took advantage of favourable financial market conditions to accomplish this. In the case of China, reserves increased from USD24.8 billion to USD3.3 trillion between 1992 and 2012. ${ }^{26}$ In the same period, Asian countries such as India, Indonesia, Malaysia, Philippines, South Korea and Thailand amassed a total of USD1.1 trillion in 2012, up from USD82.7 billion in 1992. Argentina, Brazil, Colombia, Chile, Mexico and Peru raised their reserves from USD75 billion in 1992 to 726 billion in 2012. This invaluable reserve position helped emerging economies to 'surf' the GFC in an enviable position and without requiring the assistance of the IMF. ${ }^{27}$

\section{Repayment of IMF loans}

A significant number of middle-income countries experimented with the implementation of IMF sponsored programs and did not achieve the anticipated positive macro-economic results or strengthened governance and a legal framework for the smooth operation of markets. Some were also the biggest IMF debtors and decided to anticipate payment of their debts in the 2000s to escape its strict conditionality and regain control of their domestic financial affairs. In the words of former Argentinean President Nestor Kirchner, 'Paying off the Fund will generate freedom for national decisions. ${ }^{28}$ By 2006, countries such as Argentina, Brazil, Mexico and Venezuela had repaid their loans to the IMF. Hugo Chávez, then the Venezuelan president, announced that Venezuela would withdraw from the Institution. Chávez, however, encountered some practical problems in regard to pursuing this course because withdrawal from the IMF was considered a default event under the terms of many of the bonds issued and sold by the country's government in international markets. ${ }^{29}$

Altogether, between 2004 and 2008, Latin America and the Caribbean's dependence on the IMF plummeted — outstanding loans from the General Reserve 
Account fell from $49.4 \%$ of the IMF's SDR62.153 billion loan portfolio to $6.7 \%$ of the IMF's SDR3.896 billion of outstanding loans (i.e. from SDR30.697 billion to about SDR395 million). ${ }^{30}$

Debtor repayments and the relatively good health of the economies of middleincome countries that did not require bailouts from the IMF in the period produced a dramatic reduction in IMF income (necessary to cover its operating expenditure). ${ }^{31}$ Credit outstanding of its General Reserve Account fell from a peak of SDR60. 451 billion in December 1998 to SDR6.036 billion in December 2007..$^{32}$ This prompted a debate about its future and financial viability. ${ }^{33}$

One of the outcomes of this debate was that the IMF decided that it needed to rethink its operations and adopt a new income model that included the sale of a portion of its gold reserves, expansion of investment strategies to generate higher returns, and reinstatement of the practice of recovering costs that the IMF incurs in the operations of the trust fund for concessional lending to low-income countries by reimbursing the General Resource Account for these costs. ${ }^{34}$ The IMF also decided to reduce its bureaucracy.

Paradoxically, the GFC provided the IMF with an 'unexpected' opportunity to recover from the reduction of income with the arrival of new European 'clients' affected by the GFC. ${ }^{35}$ Its total credit outstanding portfolio rose to SDR21. 487 billion by December 2008 from SDR9. 833 billion a year earlier, further increasing to a peak of SDR95.808 billion in December 2012. ${ }^{36}$ Nonetheless, it is difficult to find a Latin American or Asian middle-income country among current IMF debtors. Pakistan is the only Asian country that has a current arrangement with the institution funded by the General Reserve Account and Bangladesh has a facility supported by the Poverty 
Reduction and Growth Trust (Table 1). Colombia, Mexico and Honduras have current arrangements with the IMF but they have not withdrawn money from those facilities.

\section{Reforms of IMF governance and the role of the new G20}

As developing countries became more financially sound, they started demanding reforms of IMF's governance in order to achieve greater transparency in the design of policies and programs. The IMF viewed these claims as an opportunity to attract money from emerging economies with large international reserves; the increase of emerging economies' quotas would boost IMF's resources available to address financial crises. To capture the support of middle-income countries, the IMF agreed to review several policies, including the allocation of quotas among members in order to increase developing nations' voting power.

After lengthy negotiations, in 2005 IMF members achieved an initial agreement to implement a new policy of quota allocation that began to be implemented in 2008 with an ad-hoc quota increase for 54 members. Then, in 2010, the members agreed upon a set of reforms contained in the $14^{\text {th }}$ General Review of Quotas that introduces a historic doubling of quotas and a major realignment of quota-shares that involves a shift of more than $6 \%$ from over-represented to under-represented members and more than $6 \%$ quota shift to developing countries. ${ }^{37}$ The greatest beneficiaries of these changes would be among emerging economies. In the particular case of China, its IMF quota would rise from $2 \%$ to $6.4 \%$. Another innovative reform approved was to move to a more representative Executive Board with all members elected to the Board.

The $14^{\text {th }}$ General Review of Quotas reform involves an amendment to the IMF Articles of the Agreement. ${ }^{38}$ For the amendment to come into effect, it needs acceptance by at least three-fifths of IMF members, representing $85 \%$ of the total voting power 
(Article XXVIII). Members agreed that they would make their best efforts to complete their domestic approval processes by October 2012; however, the amendment has not entered into force at August 2015.

These reforms — known as 'the voice and participation reforms' — represent a step in the right direction to strengthening the participation of developing countries in IMF governance; however, it does not significantly change the way in which the IMF makes its decisions. When the reforms enter in force, almost $47 \%$ of IMF voting power will be still controlled by nine developed countries, and the US vote (17\%) will be still needed to pass important decisions where a qualified vote of $85 \%$ is required, including the implementation of the new SDR quota system and the reform of the Executive Board (Table 2). ${ }^{39}$ An example of the difficulties faced by members' attempts to give developing countries more voice is the fact that these reforms have not come into effect as the US Congress has not approved the proposed changes, although the vast majority of the IMF members have already accepted the proposed SDR quotas (members representing $77 \%$ of the total voting powers) and the reform of the Executive Board (members representing $80 \%$ of the voting powers). ${ }^{40}$

At the same time that the IMF was working on strengthening the voting share of developing countries in 2008 , major industrialised economies decided to implement another strategy to retain control of the Institution and of the global financial order in general. That year, the importance of the G20 was significantly altered. Initially formed in 1999 during the AFC by the G7 finance ministers (in the face of some opposition from the IMF which not unreasonably viewed it as a rival) and meeting at least annually thereafter, these meetings of finance ministers and central bank governors attempted to move to this forum the relevant discussions on policies, programs and key decisions. ${ }^{41}$ Its status markedly increased when, as the GFC began to impact on an increasing 
number of national economies, G20 'Summits' (heads of government meetings) were held in addition to G20 meetings of finance ministers and central bank governors. The G20 became more widely accepted (even within the IMF) as an avenue for the making of decisions and the formulation of policies to be adopted by the IMF to deal with the rolling crises. ${ }^{42}$

This group defines itself as 'the premier forum for international economic cooperation. ${ }^{43}$ The $\mathrm{G} 20$ represents countries responsible for $85 \%$ of the global economy and includes developed countries (Australia, Canada, France, Germany, Italy, Japan, South Korea, Turkey, UK and US), and emerging nations (Argentina, Brazil, China, India, Indonesia, Mexico, Russia, Saudi Arabia and South Africa). The European Union is also a member of the G20.

The pragmatic implication of the strengthening of the G20 is that this plurilateral forum has divided developing countries into two groups: the first formed by those emerging markets that are ranked within the biggest global economies and are represented in the G20; and the second, that of developing countries whose economies contribute less than $15 \%$ of the global input and are represented in the IMF but not in the G20.

The use of a plurilateral approach instead of multilateralism has become common where major industrialised economies have found it difficult to negotiate multilateral agreements in a way that accommodates their interests due to the multiplicity of countries with vast and competing interests. ${ }^{44}$ In the case of the IMF, it seems easier for developed countries to negotiate with ten emerging economies within the context of the G20 rather than a greater number of IMF members; however, this approach delegitimises smaller economies in both categories, muting their voices, 
concerns and contributions in the fundamental process of decision and policy making and program design.

\section{Regional forums}

Another strategy employed by developing countries to reduce IMF influence has been the organisation of regional forums that can be a more reliable and less intrusive source of emergency funds in the event of financial crises. While major industrialised countries have been willing to create plurilateral forums to group like-minded countries (e.g., Anti-Counterfeiting Trade Agreement (ACTA)) and to address regional problems (e.g., European Financial Stability Facility), they have opposed the use of similar strategies by developing countries. In the aftermath of the AFC, for example, Japan suggested the creation of an Asian monetary fund, a proposal that was opposed by the US Treasury Department, which argued that such a regional fund would undermine the IMF by lending money with inconsistent policy conditions. ${ }^{45}$ Consequently, the idea was dismissed and the ASEAN members together with China, Japan and South Korea agreed, under the Chiang Mai Initiative, to a bilateral system of currency swaps (rather than a new regional financial institution) to assist nations affected by future crises.

Although initially the arrangement was thought to exclude any IMF involvement, the final product, the Chiang Mai Initiative Multilateralisation (CMIM), has been designed as an IMF supplementary mechanism. The CMIM is currently a USD240 billion self-managed reserve pooling mechanism that provides short-term swap facilities to countries in need. ${ }^{46}$ Each economy's swap quota depends on its CMIM pool contribution, its level of development, and size. If a country requests to use more than $30 \%$ of its CMIM quota, the transaction must be linked to an IMF program; ${ }^{47}$ thus, the IMF has the capacity to influence conditionality for most of the swaps conducted under this arrangement. This prevents circumstances arising where a country affected by a 
financial crisis receives assistance from both sources (i.e. IMF and CMIM) under conditions that may be contradictory. Whilst China and Japan each contributed with $32 \%$ of the CMIM funds, decisions on fundamental issues associated with the Initiative must be approved by consensus which is a main difference with the IMF governance.

With less success than its Asian counterparts, South America has also sought alternative options to face financial crises, avoiding the IMF. As early as 1976, Andean member countries of the 1969 Cartagena Agreement on Andean Sub-regional Integration (Bolivia, Ecuador, Colombia, Peru, and Venezuela) founded the Andean Reserve Fund (Fondo Andino de Reservas (FAR)). In 1989, the FAR became the Latin American Reserve Fund (Fondo Latinoamericano de Reservas (FLAR)) and tried to attract members more widely from Latin America. This was met with very limited success — only Costa Rica and Uruguay joined the Fund (in 2000 and 2009 respectively). FLAR's low capital resources — USD2.3 billion — is the reason that its role remained very limited, and why South American nations sought IMF financial assistance in the 1990s instead.

Banco del Sur is a more recent initiative to build an alternative international financial architecture in South America. This IFI was originally agreed upon by Venezuela and Argentina in 2006, ${ }^{48}$ with Bolivia, Brazil, Ecuador, Paraguay and Uruguay joining subsequently. The complex negotiations to create the Bank took longer than expected due to participants' divergent perspectives on the functions that the new IFI should assume. Countries such as Ecuador advocated the adoption of a more ambitious model that created an alternative regional financial architecture that would include Banco del Sur and Fondo del Sur, the latter a type of regional monetary fund, while nations such as Brazil backed a more modest proposal that envisaged the Banco del Sur providing only financial assistance for development. 
The negotiating countries finally signed an agreement to create the new regional institution in 2009. Banco del Sur possesses start-up capital of USD7 billion (USD20 billion pledged). Argentina, Brazil and Venezuela initially contributed with USD2 billion each; Ecuador and Paraguay USD400 million each; and Bolivia and Paraguay USD100 million each. In spite of the uneven contributions, each member has one vote, and decisions are made by a qualified majority in case of structural matters and major financing projects decisions, and by a simple majority for other decisions on operational matters. ${ }^{49}$ Banco del Sur has not started providing loans yet and it is unclear whether it would incorporate conditions into its agreements; however, one of the goals of the Bank is to offer financial instruments that are compatible with the economic and fiscal policies of each beneficiary country; thus, it is unlikely that the institution will include IMF-type of conditionality that affect national policies.

Some commentators have suggested that Banco del Sur is more a political project than a serious and articulated financial response to future South American crises. ${ }^{50}$ They argue that ideological differences among its members will impede efficient operation. Others see the new regional institution as a welcome player that will contribute fresh ideas to the development debate and serve as a counterbalance to the influence of Western-controlled IFIs such as the IMF and the World Bank. ${ }^{51}$

Most recently, Brazil, Russia, India, China and South Africa (BRICS) ${ }^{52}$ established a far more ambitious project, the New Development Bank (NDB BRICS), which is a development institution with capital of USD100 billion with each member contributing with USD20 billion. (Initial capital was set at USD50 billion.) Headquartered in Shanghai, the NDB BRICS will provide financing for infrastructure and development. Different from the Bretton Woods institutions, each member of the Bank has equal voting power. Additionally, the NDB BRICS will manage a 
Contingency Reserve Arrangement of USD100 billion to assist countries to address short-term liquidity problems. The pool will be funded with a contribution of USD41 billion from China, while Brazil, India and Russia will each contribute USD18 billion, and South Africa USD5 billion.

The NDB BRICS represents another alternative for sourcing development finance for developing countries. The Agreement establishing the NDB BRICS does not contain references to fiscal o monetary conditions for transactions with non-member countries but it grants the Board of Governors with powers to issue general policies setting conditions under which those transactions can be conducted (Article 19).

\section{Cooperation: South-North and South-South}

Whilst Michel Camdessus, IMF Managing Director between 1987 and 2000, was an unwelcome guest of many developing countries in the 1990s, Christine Lagarde, the current head of the Institution, has been perceived more positively. Her role has been quite different from the one undertaken by Camdessus when she toured Asia and Latin America after the onset of the GFC, trying to encourage leaders of emerging economies to financially contribute to the European Financial Stability Facility (EFSF), created to deal with European countries affected by the GFC. The intervention of Lagarde was fruitful, and countries such as Brazil and Indonesia pledged their support to the IMF and the EFSF. In this scenario, emerging economies were involved in a cooperation that could be labelled 'South-North'. Nevertheless, in spite of the fact that emerging economies have moved from being recipients of IMF financial assistance to contributors of funds to assist European countries in crisis, their influence over decisions that affect the international financial system is still limited, as was noted above. 
Innovation is also perceptible in the field of development cooperation among developing nations, with several middle-income countries having become influential players alongside traditional actors. ${ }^{53}$ Brazil, Russia, India, China and South Africa provided development assistance for the amount of USD3.9 billion in 2009, with China accounting for $50 \%$ of that total. ${ }^{54}$ Whilst most traditional development and financial programs sponsored by IFIs and members of the Development Assistance Committee of the Organisation for Economic Cooperation and Development (DAC) ${ }^{55}$ incorporated conditionality that requires the implementation of fiscal, monetary and structural measures aligned with the market-economy model, development cooperation procured by nations of the South has proved popular due mainly to the exclusion of governance and policy conditions.

China, for example, provides non-conditional financial assistance to countries in Asia, Latin America and Africa. The Chinese government has developed its own set of principles to guide the provision of foreign aid and they differ from those developed under the DAC umbrella. ${ }^{56}$ Chinese in this area have described the country's SouthSouth cooperation as collaboration among sovereign states to achieve mutual benefits. ${ }^{57}$ China's financial assistance does not generally attach policy or governance conditionality. The country considers itself as 'developing' too; thus, it assumes development assistance is a mechanism that facilitates the exchange of development experiences with other like-minded countries. China's assistance has benefited 93 countries in Latin America, Africa and Asia. A recent study has estimated that, in 2011 alone, China made new commitments for foreign aid for an amount close to USD189.3 billion which was equivalent to about $3 \%$ of the country's GDP. ${ }^{58}$ Other more conservative studies estimate Chinese foreign aid in USD7 billion in 2013. ${ }^{59}$ 
At the 2011 OECD Fourth High Forum on Aid Effectiveness in Busan (South Korea), IFIs and DAC countries initially tried to agree with emerging economies from the BRICSAM group (Brazil, Russia, India, China, South Africa and Mexico) on a set of unified principles that would guide the provision of financial assistance for development. ${ }^{60}$ However, participants could not reach agreement, although they supported the final declaration in which it was recognised that modalities and responsibilities that apply to South-South cooperation differ from those that apply to North-South cooperation. ${ }^{61}$ BRICSAM's position was relevant, particularly for China that (as was emphasized earlier) provides substantial financial development aid without attaching conditions that are common in IFI sponsored programs. Consequently, BRICSAM has not joined the aid effectiveness panel that was created in the Busan meeting. ${ }^{62}$ The financial assistance offered by China could be considered as politically and economically motivated. For many developing countries; however, it is as an opportunity to access financial assistance in competitive terms without structural conditionality.

\section{The rise of emerging economies and the future of Law and Development}

The expansion of development cooperation sources as well as the rising influence of emerging economies has been reflected in the field of Law and Development. Different from the precedent moments where the debate was highly influenced by IFIs and wealthier developed countries, relying heavily on theoretical frameworks that originated in Western universities and 'think-tank' institutions, the current moment reflects more fairly the interest of developing countries. 
The Global South has assumed a more proactive role in the definition of development cooperation and deciding how law should be interconnected with the development process. The change can be perceived in the increase number of collaborative projects that involve Western and developing-country institutions, academics and practitioners. This collaboration is the source of new ideas that capture a more accurate picture of each developing country and avoid the formulation of grandtheories. ${ }^{63}$ Instead of a debate focused on single developed nations IFI agenda, multiple agendas with a more pluralistic content have arisen where several approaches compete and non-traditional providers of development assistance offer alternative development aid products.

In this pluralistic scenario, there is no a unique role for law. Whilst it is still common to find academic studies influenced by the old schools of Law and Development that advocates for the modernisation of law and the strengthening of the rule of law, it is also becoming more familiar to find innovative perspectives that use the law in different ways. A good example reviewed in this article is the way in which developing countries are using a more equalitarian conception of international economic law in forums such as Banco del Sur, the NDB BRICS and CMIM in order to build more transparent and legitimate governance systems. This approach is a clear reaction of the South to governance of traditional IFIs that uses economic and political power as sole factors to allocate voting rights, concentrating the decision-making process in a small group of countries.

On the other hand, the IMF remains unchanged. The onset of the GFC overshadowed the debate on the future of the institution and its overdue governance reform. The Global South responded to the slow process of IMF reforms by using a 
more assertive approach, creating innovative mechanisms for mutual development cooperation as well as gestating new forums and institutions.

Although emerging economies still do not have a key role in the decisionmaking process of the international financial order, they are demonstrating political maturity and the financial strength to explore new alternatives that do not necessarily have to agree completely with US and European models. This reality does not mean that emerging economies will completely depart from a market economic model or that they will not support initiatives to strengthen the rule of law. They will continue to develop a market-oriented economy and work on a concept of the rule of law in order to promote democracy, human rights and a market economy but, contrary to the traditional IFI approach, these nations will envisage methods and mechanisms that consider local circumstances, experience and interests. In spite of the optimism of this article about the future of Law and Development, other authors opt for a more cautious view and remind us of the limits of law to support development and address the deep problems of inequality still faced by many developing countries. ${ }^{64}$

\section{Notes}

1 See Trubek and Santos, "Introduction;" and Ohnesorge, "Law and Development Orthodoxies."

2 Trubek and Santos, "Introduction." The literature associated with Law and Development is extensive and is generally discussed following this three-moment approach which basically captures what Ohnesorge calls 'Law and Development orthodoxies.' See Ohnesorge, "Law and Development Orthodoxies." However, there is a valuable body of research that is not adequately reflected in this approach. See also note 17.

3 Weber, Economy and Society, 337.

4 However, Weber conceded that England was an exception: a country that achieved development without a 'rational legal system'.

5 Galanter, "The Modernization of Law," 167.

6 See e.g., Seidman, "Law and development," 315.

7 Trubek, "Toward a Social Theory." 
Trubek and Galanter, "Scholars in Self-Estrangement."

9 North, Institutions.

10 Ibid., 54.

11 See e.g., World Bank, World Development Report 2002.

12 Roaf et al, 25 Years of Transition.

13 See eg, IMF, Summary Proceedings.

14 Antons, "Law and Development Thinking After the Asian Crisis."

15 'Best practice' is an ambiguous term that was commonly used by IFIs in the 1990s to encourage developing countries to adopt a set of 'tested' principles and regulations in legal areas such as banking law, corporations law, tax law, etc. For example, the Basel Committee on Banking Supervision, an international forum for cooperation on banking supervision, issued in 1997 a document titled 'Core Principles for Effective Banking Supervision.' According to the document, national authorities should incorporate these principles in their legal system in order to achieve 'best supervisory practices.' The Basel Committee document provided the blueprint for banking reforms promoted by the IMF. See, Basel Committee on Banking Supervision, Core Principles.

16 Trubek discussed in great detail of the use of the rule of law during the second moment. See Trubek, "The 'Rule of Law'."

17 Newton, "The Dialectics of Law," 199. The first Commonwealth School described by Newton opposed the initial Law and Development movement which was considered an instance of neo-colonialism. For examples of the Second School see, Peerenboon, China's Long March; Antons and Gessner (eds), Globalisation and Resistance; Antons, Law and Development. Upham who also has studied the link between law and development in East Asia has questioned the existence of such connection. See Upham, 'Speculations on Legal Informality.'

18 Sen, "What is the Role."

19 IMF, Key Features of IMF Poverty.

${ }^{20}$ For a recent work that discusses the current debate, see Trubek, "Law and Development."

${ }^{21}$ See e.g., Beattie, "Washington's Warning Way.” Photo features former Indonesian President Suharto signing the 1998 IMF agreement while the then IMF Managing Director, Michel Candessus, was standing over him.

22 Some governments used the argument that SBAs were not legal international agreements to agree reforms with the IMF without consulting legislative bodies. See Leckow, "The Standby Arrangement" 38; and Garcia "Understanding IMF Stand-by Arrangements."

23 See Williamson, "Latin American Reform," 107.

24 Rapley, Understanding Development Theory, 62.

25 See e.g., Stiglitz, Globalization and Its Discontents; and Bello, Rau and Cunningham, Dark Victory.

${ }^{26}$ International reserves figures are based on the World Bank data (available at World Bank, Data: Total Reserves (Includes Gold, Current USD; accessed May 14, 2015) http://data.worldbank.org/indicator/FI.RES.TOTL.CD. 
Mexico agreed with the IMF on a Flexible Credit Line arrangement in April 2009 for SDR31. 528 billion; however, it was a precautionary measure taken by authorities due to a sharp drop of GDP growth caused by the GFC. It has been extended four times, most recently in November 2014 but Mexico has not withdrawn money using it. Colombia completed a similar IMF arrangement in May 2010 for the amount of SDR2. 322 billion. Last renewed in June 2013, the credit facility has not been utilised.

${ }^{28}$ See "Kirchner and Lula: Different Ways to Give the Fund the Kiss Off: Argentina, Brazil and the IMF," The Economist, December 20, 2005.

${ }^{29}$ See for instance the events of default included in the following documents:Bolivarian Republic of Venezuela, Prospectus Offer to Exchange its US Dollar-Denominated 10.75\% Notes due 2013, registered under the Securities Act of 1933 ('Exchange Notes') for its Outstanding US-Denominated 10.75\% Notes due 2013, 2004; Bolivarian Republic of Venezuela, Listing Memorandum 7.65\% Bonds due 2025, 2005.

30 IMF, Financial Statement 2005, Appendix VII, 157; and IMF Financial Statement 2009, Appendix VI, 10.

31 See IMF, Committee to Study Sustainable Long-Term Financing.

32 MF, Total IMF Credit Outstanding for All Members from 1984-2015. (accessed May 12, 2015) http://www.imf.org/external/np/fin/tad/extcred1.aspx. The IMF provides financial assistance to its middle-income members from resources in its General Reserve Account. In the case of low-income countries, the IMF manages a trust (Poverty Reduction and Growth Trust (PRGT)) that provides financial resources for low-income countries with financial problems.

33 See IMF, Committee to Study Sustainable Long-Term Financing.

34 Burke, "IMF Income Model."

35 Peter Doyle, a former IMF European Department senior economist, claimed that although the IMF had identified well in advance the incubation of the GFC, it did not provide timely warnings to members. Richard Blackden. 2012. "Debt Crisis: IMF 'Supressed Signs that Europe Was Facing Debt Crisis'.” The Telegraph, July 20. http://www.telegraph.co.uk/finance/financialcrisis/9416608/Debt-crisis-IMF-suppressedsigns-that-Europe-was-facing-debt-crisis.html.

36 IMF, Total IMF Credit Outstanding for All Members from 1984-2015. (accessed May 12, 2015) http://www.imf.org/external/np/fin/tad/extcred1.aspx.

37 IMF, IMF Quota and Governance.

38 The Articles of Agreement is the international treaty that governs the organisation's management and operations.

39 The IMF quota of each state member is calculated using a complex formula that considers weighted average of GDP (50\%), openness (30\%), economic variability (15\%), and international reserves $(5 \%)$.

40 IMF, Acceptances of the Proposed Amendment. For an explanation of some of the US reasons for being against the IMF reforms, see e.g., Nelson and Weiss, IMF Reforms.

${ }^{41}$ Kirton, G20 Governance. See Preface for launch, Chapter 1 for early days (i.e. 1999 to 2008 summary) and early Pt II i.e. ch 3, where the lack of standardised criteria for inclusion is revealed (author cites Wade, "From Global Imbalances," 539. For the initial idea as a bypass of IMF, see Brown, Beyond the Crash. 
See Cammack, "The G20, the Crisis." See also Kirton, G20 Governance, ch 3.

43 Australian Department of Foreign Affairs and Trade, The G20. (accessed November 20, 2012). http://www.dfat.gov.au/trade/g20/index.html.

44 ACTA is a recent example. This plurilateral treaty was negotiated and signed by like-minded countries to strengthen the international legal framework for the speedy enforcement of intellectual property rights, avoiding debate that slows negotiations in forums such as the World Intellectual Property Organisation (WIPO) and the World Trade Organisation (WTO). See Antons and Garcia, "Initiatives on IP Enforcement."

${ }^{45}$ China also opposed the Japanese idea of creating an Asian monetary fund. See Ciorciari, "Chiang Mai Initiative."

${ }^{46}$ Sussangkarn, "Chiang Mai Initiative Multilateralization."

47 Bangko Sentral ng Pilipinas, Chiang Mai Initiative.

48 Gómez González, "Banco del Sur," 46.

49 Rosales, "The Banco del Sur," 32.

50 See e.g., Webber and Mander, "Argentina Backs Banco del Sur Project"”;" and Artana, "Why Banco del Sur."

${ }^{51}$ Carroll, "Nobel Economist Endorses Chávez Regional Bank."

52 BRICS is an informal group born from a Summit celebrated in Yekaterinburg, Russia, in 2009. The group organises annual summits.

53 See World Bank, Global Monitoring Report 2012, 137-159; Dehart, "Remodelling the Global Development"; and Kim and Lightfoot, "Does 'DAC-Ability' Really Matter?"

54 World Bank, Global Monitoring Report, 138. While most of the attention on development cooperation by emerging economies focuses on BRICS countries, there are other developing nations in Latin America, Eastern Europe and the Middle East that provide development assistance. See Zimmermann and Smith, "More Actors, More Money."

55 DAC monitors and shares information on the architecture of official development assistance provided by state members to help ensure its transparency and effectiveness. DAC members comprise 23 countries and the European Union, and include Canada, France, Germany, UK, South Korea, US and Japan. See more information at DCD-DAC http://www.oecd.org/dac/.

56 See, the State Council of the People's Republic of China, China's Foreign Aid. See also, Sanderson and Forsythe, China's Superbank.

57 See also M Dehart, "Remodelling the global development landscape".

58 See Wolf, Wang and Warner, China's Foreign Aid, 18. The authors explain the difficulties that they faced to define Chinese foreign aid and the inadequacy of the OECD term "official development assistance". Chinese foreign aid includes arrangements that they call "government-sponsored investment activities".

59 Kitano and Harada, "Estimating China's Foreign Aid."

${ }^{60}$ See Kilby, "The Changing Development Landscape, 1004. BRICSAM is generally uses to refer to the emerging economies of the BRICS countries plus Mexico. BRICSAM countries often act an ad-hoc group and present a common position in international forums such as the United Nations. 
${ }^{61}$ OECD, "Busan 'Partnership for Effective Development Cooperation'," $4^{\text {th }}$ High Forum on Aid Effectiveness, Busan, Republic of Korea, 29 November - 1 December 2011.

62 However, according to an article published in August 2012, other emerging economies such as Nigeria and Indonesia appointed officials to the panel: Mark Tran. 2012. "Nigerian and Indonesian Officials Join Post-Busan Aid Effectiveness Panel," The Guardian, August 7

${ }^{63}$ See e.g., Trubek et al, Law and the New Developmental State. Another example is a recent publication on Law and Economics in China by Kennedy and Stiglitz, where the collaborators address questions on law and economic development considering the particular characteristics of the Chinese phenomenon Kennedy and Stiglitz (eds), Law and Economics.

${ }^{64}$ See e.g., Tamanaha, 'The Primacy of Society'; Vilhena Vieira, 'Inequality and the subversion'

\section{Bibliography}

Antons, Christoph, ed. Law and Development in East and Southeast Asia. Richmond: RoutledgeCurzon, 2003.

Antons, Christoph. "Law and Development Thinking after the Asian Crisis of 1997." Forum of International Development Studies 20, no. 12 (2001): 205-232.

Antons, Christoph, and Gabriel Garcia. "Initiatives on IP Enforcement beyond TRIPS: The Anti-Counterfeiting Trade Agreement and the International Medical Products AntiCounterfeiting Task Force." In The Enforcement of Intellectual Property Rights: Comparative Perspectives from the Asia-Pacific Region, edited by Christoph Antons, 125-159. Alphen aan den Rijn: Kluwer Law International, 2011.

Antons, Christoph, and Volkmar Gessner, eds. Globalisation and Resistance: Law Reform in Asia since the Crisis. Oxford: Hart, 2007.

Artana, Daniel. 2010. "Why Banco del Sur Is a Bad Idea.” Americas Quarterly, February 24. http://www.americasquarterly.org/artana-banco-del-sur

Bangko Sentral ng Pilipinas. Chiang Mai Initiative Multilateralization. Manila, June 2015.

Basel Committee on Banking Supervision, Core Principles for Effective Banking Supervision, 2012. http://www.bis.org/publ/bcbs230.htm

Beattie, Alan. 2008. "Washington's Warning Way: How Bail-Outs Poison a Free Market Recipe for the World." Financial Times, September 28. http://www.ft.com/cms/s/0/55523548-8d73-11dd-83d5-

0000779fd18c.html\#axzz3kHHQr94x 
Bello, Walden F, Bill Rau, and Shea Cunningham, Dark Victory: The United States, Structural Adjustment and Global Poverty. London: Pluto, 1994.

Brown, Gordon, Beyond the Crash: Overcoming the First Crisis of Globalization. New York: Free Press, 2010.

Burke, Maureen. 2008. "IMF Income Model Has Five Key Elements.” IMF Survey Online, April 8.

https://www.imf.org/external/pubs/ft/survey/so/2008/NUM040808A.htm

Cammack, Paul. "The G20, the Crisis and the Rise of Global Developmental

Liberalism." Third World Quarterly 33, no. 1 (2012): 1-16.

Carroll, Rory. 2007. "Nobel Economist Endorses Chávez Regional Bank Plan.” The Guardian, October 12.

Ciorciari, John. "Chiang Mai Initiative Multilateralization: International Politics and Institution-Building in Asia ('CMIM').” Asian Survey 5 (2011): 953-970.

Dehart, Monica. "Remodelling the Global Development Landscape: The China Model and the South-South Cooperation in Latin America." Third World Quarterly 33, no. 7 (2012): 1359-1375.

Galanter, Marc, “The Modernization of Law." In Modernization: The Dynamics of Growth, edited by M Wiener, 167-179. New York: OUP, 1966.

Garcia, Gabriel. "Understanding IMF Stand-By Arrangements from the Perspective of International and Domestic Law: The Experience of Venezuela in the 1990s." Paper presented at the $3^{\text {rd }}$ Biennial Global Conference of the Society of International Economic Law (SIEL), Singapore, July 12-14, 2012.

Gómez González, Ileana Amarilis. "Banco del Sur, Nueva Estructura Financiera de los Países Suramericanos para el Desarrollo de la Región." LLM diss., Universidad Central de Venezuela, 2012.

IMF, Acceptances of the Proposed Amendment of the Articles of Agreement on Reform on the Executive Board and Consents to 2010 Quota Increase. Washington: September 4, 2014. http://www.imf.org/external/np/sec/misc/consents.htm

IMF, Committee to Study Sustainable Long-Term Financing of the IMF: Final Report. Washington: January 31, 2007. http://www.imf.org/external/np/oth/2007/013107.pdf

IMF, Financial Statement 2005, Appendix VII. http://www.imf.org/external/pubs/ft/ar/2005/eng/pdf/file8.pdf

$I M F$, Financial Statement 2009, Appendix VI. http://www.imf.org/external/pubs/ft/ar/2009/eng/pdf/a6.pdf

IMF, IMF Quota and Governance, Washington: September 11, 2013. http://www.imf.org/external/np/fin/quotas/pubs/index.htm

IMF, Key Features of IMF Poverty Reduction and Growth Facility (PRGF) Supported Programs. Washington: August 16, 2000. http://www.imf.org/external/np/prgf/2000/eng/key.htm 
IMF, Summary Proceedings of the Fifty-First Annual Meeting of the Board of Governors. Washington: 1996.

http://www.imf.org/external/pubs/ft/sum51/pdf/part05.pdf

Kennedy, David, and Joseph Stiglitz, eds. Law and Economics with Chinese

Characteristics: Institutions for Promoting Development in the Twenty-First Century.

Oxford: Oxford University Press, 2013.

Kilby, Patrick. "The Changing Development Landscape in the First Decade of the $21^{\text {st }}$ Century and its Implications for Development Studies." Third World Quarterly 33, no. 6 (2012): 1001-1017.

Kim, Soyeun, and Simon Lightfoot. "Does 'DAC-Ability' Really Matter?” Journal of International Development 23, no. 5 (2011): 711-721.

Kirton, John. G20 Governance for a Globalized World. Farnham: Ashgate, 2013.

Kitano, Naohiro, and Yukinori Harada. "Estimating China's Foreign Aid 2001-2013." Journal of International Development (forthcoming 2015). doi: 10.1002/jid.3081.

Leckow, Ross. "The Stand-By Arrangement: Its Legal Nature and Principal Features." In Current Developments in Monetary and Financial Law Vol 2. 33-49. IMF, 2003.

Nelson, Rebecca, and Martin Weiss. IMF Reforms: Issues for Congress. Washington: Congressional Research Service, March 11, 2014.

Newton, Scott. "The Dialectics of Law and Development." In The New Law and Economic Development: A Critical Appraisal, edited by David Trubek and Alvaro Santos, 174-202. Cambridge: Cambridge University Press, 2006.

North, Douglass. Institutions, Institutional Change and Economic Performance. Cambridge: Cambridge University Press, 1990.

Ohnesorge, John. "Law and Development Orthodoxies and the Northeast Asian Experience." In Law and Development in Asia, edited by Gerald Paul McAlinn, and Caslav Pejovic, 9-42. New York: Routledge, 2012.

Peerenboom, Randall. China's Long March toward Rule of Law. Cambridge: Cambridge University Press, 2005.

Rapley, John. Understanding Development. Theory and Practice in the Third World. $2^{\text {nd }}$ ed. Boulder: Lynne Rienner Publishers, 2002.

Roaf, James, Ruben Atoyan, Bikas Joshi, and Krzysztof Krogulski. 25 Years of Transition Post-Communist Europe and the IMF, Regional Economic Issues Special Report. Washington: IMF, 2014.

Rosales, Antulio. "The Banco del Sur and the Return to Development." Latin American Perspectives 40, no. 5 (2013): 27-43.

Sanderson, Henry and Michael Forsythe. China's Superbank: Debt, Oil and Influence - How China Development Bank is Rewriting the Rules of Finance. Singapore: John Wiley \& Son, 2013.

Seidman, Robert. "Law and Development: A General Model." Law and Society Review 6, no. 3 (1972): 311-342. 
Sen, Amartya. "What is the Role of Legal and Judicial Reform in the Development Process?" Paper presented at the Role of Legal and Judicial Reform in Development, World Bank Conference, Washington, DC, June 5, 2000.

State Council of the People's Republic of China, China's Foreign Aid, White Paper (2014). Accessed August 30, 2015.

http://english.gov.cn/archive/white_paper/2014/08/23/content_281474982986592.htm

Stiglitz, Joseph E. Globalization and Its Discontents. New York: Norton Publishers, 2003.

Sussangkarn, Chalongphob. "Chiang Mai Initiative Multilateralization: Origin, Development, and Outlook." Asian Economic Policy Review 6, no. 2 (2011): 203-220.

Tamanaha, Brian. "The Primacy of Society and the Failures of Law and Development." Cornell International Law Journal 44, no. 2 (2011): 209-247.

Trubek, David. "Law and Development: 40 Years after Scholars in Self Estrangement A Preliminary Review." University of Wisconsin Law School. Legal Studies Research Paper Series Paper No. 1255: Madison, 2014.

Trubek, David. "The 'Rule of Law' in Development Assistance: Past, Present, and Future. In The New Law and Economic Development: A Critical Appraisal, edited by David Trubek and Alvaro Santos, 74-94. Cambridge: Cambridge University Press, 2006.

Trubek, David. "Toward a Social Theory of Law: An Essay on the Study of Law and Development." Yale Law Journal 82, no. 1 (1972): 1-50.

Trubek, David, and Marc Galanter. "Scholars in Self-Estrangement: Some Reflections on the Crisis in Law and Development Studies in the United States." Wisconsin Law Review 4, no. 4 (1974): 1062-1102.

Trubek, David, Helena Alviar Garcia, Diogo Coutinho, and Alvaro Santos, eds. Law and the New Developmental State: The Brazilian Experience in Latin American Context. Cambridge: Cambridge University Press, 2013.

Trubek, David, and Alvaro Santos. "Introduction: The Third Moment in Law and Development Theory and the Emergence of a New Critical Practice." In The New Law and Economic Development: A Critical Appraisal, edited by David Trubek and Alvaro Santos, 1-18. Cambridge: Cambridge University Press, 2006.

Upham, Frank K. "Speculations on Legal Informality: In Winn's 'Relational Practices and the Marginalization of Law': Comment." Law and Society Review 28, no. 2 (1994): 233-242.

Vilhena Vieira, Oscar. "Inequality and the Subversion of the Rule of Law." In Law and Society in Latin American: A New Map, edited by César Rodríguez-Garavito, 23-42. New York: Routledge, 2015.

Wade, Robert. "From Global Imbalances to Global Reorganisations." Cambridge Journal of Economics 33, no. 4 (2009): 539-562. 
Webber, Jude, and Benedict Mander. 2011. "Argentina Backs Banco del Sur Project." The Financial Times, September 7. http://www.ft.com/intl/cms/s/0/d0b95244-d97d11e0-b52f-00144feabdc0.html\#axzz3kHHQr94x

Weber, Max. Economy and Society: An Outline of Interpretive Sociology. 2 vols. Multiple translators and edited by Guenther Roth and Claus Wittich, Berkeley: University of California Press, 1978

Williamson, John. "Latin American Reform: A View from Washington." In Economic Reform in Latin America, edited by Harry Costin and Hector Vanolli, 106-111. Orlando: Dryden Press, 1998.

Wolf, Charles, Xiao Wang, and Eric Warner, China's Foreign Aid and GovernmentSponsored Investment Activities. Santa Monica: National Defense Research Institute, 2013.

World Bank, World Development Report 2002: Building Institutions for Markets. Washington: World Bank, 2001.

Zimmermann, Felix, and Kimberly Smith. "More Actors, More Money, More Ideas for International Development Co-operation." Journal of International Development 23, no. 5 (2011): 722-738. 
Table 1. IMF debtors in Asia and Latin America and the Caribbean (May 2015)

\begin{tabular}{|c|c|c|c|c|c|}
\hline Country & $\begin{array}{c}\text { Type of } \\
\text { arrangement }\end{array}$ & Date of arrangement & Expiration Date & $\begin{array}{c}\text { Amount } \\
\text { Approved } \\
\text { (SDR million) }\end{array}$ & $\begin{array}{c}\text { Amount Drawn } \\
\text { (SDR million) }\end{array}$ \\
\hline Bangladesh & ECF & April 2012 & April 2015 & 639.9 & 457.1 \\
\hline Colombia & FCL & June 2013 & June 2015 & 3,870 & 0.00 \\
\hline Honduras & Stand-by & December 2014 & December 2017 & 77.70 & 0.00 \\
\hline Honduras & SCF & December 2014 & December 2016 & 51.80 & 0.00 \\
\hline Mexico & FCL & November 2014 & November 2016 & 47,292 & 0.00 \\
\hline Pakistan & EFF & September 2013 & September 2016 & 4,393 & 2,520 \\
\hline
\end{tabular}

ECF: Extended Credit Facility

EFF: Extended Fund Facility

FCL: Flexible Credit Line

SCF: Stand-by Credit Facility (low income countries)

Stan-by: Stand-by Arrangement 
Table 2. IMF quotas and share of world GDP

\begin{tabular}{|c|c|c|c|}
\hline \multirow[t]{2}{*}{ Country } & \multicolumn{2}{|c|}{ IMF Quota (\%) } & \multirow{2}{*}{$\begin{array}{c}\text { World GDP share } \\
(\%)(a)\end{array}$} \\
\hline & Current(b) & Projected(c) & \\
\hline \multicolumn{4}{|l|}{$\begin{array}{l}\text { DEVELOPED } \\
\text { ECONOMIES }\end{array}$} \\
\hline Australia & 1.4 & 1.4 & 2.1 \\
\hline Canada & 2.7 & 2.3 & 2.5 \\
\hline France & 4.5 & 4.2 & 3.6 \\
\hline Germany & 6.1 & 5.6 & 4.7 \\
\hline Italy & 3.3 & 3.2 & 2.8 \\
\hline Japan & 6.6 & 6.5 & 8.2 \\
\hline Spain & 1.7 & 2.0 & 1.8 \\
\hline UK & 4.5 & 4.2 & 3.4 \\
\hline US & 17.7 & 17.4 & 22.4 \\
\hline TOTAL & 48.5 & 46.8 & 51.6 \\
\hline \multicolumn{4}{|c|}{ EMERGING ECONOMIES } \\
\hline Brazil & 1.8 & 2.3 & 3.1 \\
\hline China (d) & 4.0 & 6.4 & 11.4 \\
\hline India & 2.4 & 2.7 & 2.5 \\
\hline Mexico & 1.5 & 1.9 & 1.6 \\
\hline Russia & 2.5 & 2.7 & 2.8 \\
\hline South Africa & 0.8 & 0.6 & 0.5 \\
\hline TOTAL & 13 & 16.6 & 21.9 \\
\hline
\end{tabular}

(a) Based on the World Bank data available at http://data.worldbank.org/datacatalog/GDP-ranking-table

(b) International Monetary Fund, IMF Members' Quotas and Voting Power, and IMF Board of Governors (5 December 2014): as per the 2008 Amendment on Voice and Participation (entry into effect 3 March http://www.imf.org/external/np/sec/memdir/members.aspx

(c) These numbers represent the quota variations agreed upon by the $14^{\text {th }}$ General Review of Quotas to one decimal place: International Monetary Fund, Quota Formula - Data Update and Further Considerations (IMF Policy Paper, August 2014) 7 'Table 1. Distribution of Quotas and Calculated Quotas' http://www.imf.org/external/np/pp/eng/2014/070214.pdf 
(d)Includes People's Republic of China, Hong Kong \& Macao Special Administrative Regions: http://www.imf.org/external/np/sec/pr/2011/pdfs/quota_tbl.pdf 